\title{
"Failure to Pay Any Poll Tax or Other Tax": The Constitutionality of Tax Felon Disenfranchisement
}

\author{
Sloan G. Speck $\dagger$
}

The right of citizens of the United States to vote in any primary or other election for President or Vice President, for electors for President or Vice President, or for Senator or Representative in Congress, shall not be denied or abridged by the United States or any State by reason of failure to pay any poll tax or other tax.'

Any person who willfully attempts in any manner to evade or defeat any tax imposed by [the Internal Revenue Code] or the payment thereof shall ... be guilty of a felony. ${ }^{2}$

Since the founding of the country, most states in the U.S. have enacted laws disenfranchising convicted felons and ex-felons. ${ }^{3}$

\section{INTRODUCTION}

Taken at face value, the foregoing statements demonstrate an incongruence between the federal Constitution and most states' criminal codes. If the government convicts a citizen under the tax evasion provisions of the Internal Revenue Code, ${ }^{4}$ some state disenfranchisement laws preclude that citizen-now a felon-from voting. ${ }^{5}$ In this

$\dagger$ BA 2001, Rice University; MA 2004, The University of Chicago; JD 2007, The University of Chicago; PhD Candidate, The University of Chicago.

1 US Const Amend XXIV, $\$ 1$.

2 Internal Revenue Code, 26 USC $\$ 7201$ (2000).

3 The Sentencing Project, Felony Disenfranchisement Laws in the United States (Nov 2005), online at http://www.sentencingproject.org/pdfs/1046.pdf (visited Sept 29, 2007). As of November 2005 , forty-eight states disenfranchised felons during incarceration, thirty-five during parole, and thirty during probation. Twelve states prohibited some or all ex-felons from voting. Id.

426 USC $\$ 7201$.

5 Tax felons are routinely disenfranchised in at least some states. See, for example, Merritt $v$ Jones, 259 Ark 380, 533 SW2d 497, 498 (1976) (noting that a county clerk "cancelled [a tax felon's] name from the voter registration list"); Bruno v Murdock, 406 SW2d 294, 295 (Mo App 1966) ("Notified of [a tax felon's] conviction, ... the Board of Election Commissioners ... struck his name from the registration roll of eligible voters."). In addition, tax felons, like other felons, face the abrogation of other political rights. See, for example, Peach v Goins, 575 SW2d 175, 183 (Mo 1978) (upholding a sheriff's disqualification from holding public office because he was a federal tax felon); Arpagaus $v$ Todd, 225 Minn 91, 29 NW2d 810, 812-13 (1947) (collecting cases holding the same). In 2006 , the IRS produced 2,019 convictions for tax crimes (out of 3,907 in- 
sense, the right to vote depends on the payment of federal income taxes. The Constitution's Twenty-fourth Amendment, however, guarantees that the federal franchise "shall not be denied or abridged ... by reason of failure to pay any poll tax or other tax." If "other tax" includes income taxes, the text of the Twenty-fourth Amendment appears to prohibit the disenfranchisement of citizens convicted of tax felonies.

Neither courts nor scholars have addressed this facial paradox. Several state courts have found tax felons within the ambit of disenfranchisement laws, but these courts grounded their decisions in state constitutions and statutes, not the federal Constitution.' Constitutional law and voting rights scholars typically assert a functional role for the Twenty-fourth Amendment, treating it as a vehicle to end racial disparities in access to the polls. ${ }^{8}$ These scholars focus on the Amendment's abrogation of "poll taxes" but do not consider the phrase "other taxes." Although some commentators assume that "other taxes" necessarily include income taxes, none explains why this conclusory statement must be true. ${ }^{10}$ This Comment addresses whether

vestigations initiated). These numbers are small compared to the $25,948,410$ individual income tax civil penalties assessed by the IRS in 2006. Internal Revenue Service Data Book 2006, Publication 55B, tables 17 and 18 (GPO 2007). Small numbers, however, do not obviate a possible constitutional issue (though they do explain the absence of case law on the topic).

6 US Const Amend XXIV, $\$ 1$.

7 See Merritt, 533 SW2d at 502 (upholding under the Arkansas constitution a tax felon's disenfranchisement); Bruno, 406 SW2d at 295 (holding that the Missouri constitution permits the disenfranchisement of tax felons and finding that implementing statutes in fact exercise that power), citing. Barrett v Sartorius, 351 Mo 1237, 175 SW2d 787, 788, 790 (1943). See also Bruno, 406 SW2d at 295 (stating that although a disenfranchised tax felon "assert[ed] the action of the board was unconstitutional, no constitutional question was raised or ruled in the trial court and therefore none exists in the appeal"). But see Sartorius, 175 SW2d at 790 (noting, twenty-one years before the ratification of the Twenty-fourth Amendment in 1964, that states' ability to disenfranchise is "limited only by the provisions of the Fifteenth Amendment to the Federal Constitution"), quoting State v Langer, 65 ND 68, 256 NW 377, 385 (1934).

8 See, for example, Nathaniel Persily, Candidates v. Parties: The Constitutional Constraints on Primary Ballot Access Laws, 89 Georgetown L J 2181, 2208 (2001) ("Congress and the states passed the Twenty-Fourth Amendment to eliminate the poll tax as a means of disenfranchising the poor, particularly African-Americans throughout the South."); Alexander Keyssar, The Right to Vote 269 (Basic 2000) ("[T]he amendment [] stemmed more from concerns about race than class."). See also Michael J. Klarman, From Jim Crow to Civil Rights 392-93 (Oxford 2004) (describing post-Brown efforts in the Deep South to deny blacks access to the ballot).

9 The scope of the phrase "other tax" has received little attention from courts and scholars. See, for example, Johnny H. Killian, George A. Costello, and Kenneth R. Thomas, eds, The Constitution of the United States of America: Analysis and Interpretation 2107-08, 2286 (GPO 2004) (addressing the Twenty-fourth Amendment strictly in terms of poll taxes); Persily, 89 Georgetown L J at 2208 (cited in note 8) (same); Keyssar, The Right to Vote at 269 (cited in note 8) (same); Ronald D. Rotunda and John E. Nowak, Treatise on Constitutional Law: Substance and Procedure $\$ 18.31$ (West 3d ed 1999) (same).

10 See, for example, José D. Román, Comment, Trying to Fit an Oval Shaped Island into a Square Constitution: Arguments for Puerto Rican Statehood, 29 Fordham Urban L J 1681, 1695 (2002) ("The phrase 'other tax' includes income taxes"), citing Amber L. Cottle, Comment, Silent 
the Twenty-fourth Amendment invalidates state disenfranchisement provisions that apply to individuals convicted of felony evasion of federal income taxes.

This Comment argues that courts should construe the Amendment narrowly to permit the disenfranchisement of tax felons-even though the Twenty-fourth Amendment's plain language precludes states from disenfranchising tax felons for federal elections. Part I defines federal tax evasion and demonstrates that nonpayment of tax constitutes an essential element of the crime. Parts II and III elaborate a tension between felon disenfranchisement laws and the Twentyfourth Amendment. Part II establishes the broad constitutionality of state felon disenfranchisement provisions under the Fourteenth Amendment, while Part III elucidates the categorical unconstitutionality of federal election poll taxes under the Twenty-fourth Amendment. Part IV addresses the crux of this tension: whether income taxes fall within the scope of the Twenty-fourth Amendment's phrase "poll tax or other tax." Analysis of the Twenty-fourth Amendment's plain language and drafting history indicates that "poll tax or other tax" should be read broadly, as including income taxes. Part V elucidates a tension between this interpretation of the Twenty-fourth Amendment and current and past social understandings about the Amendment's function. To ameliorate this tension, this Comment proposes that courts employ a "preliminary frame" that guides the application of conventional interpretive modes. This preliminary frame indicates that the Twentyfourth Amendment should be read narrowly, as not affecting tax felon disenfranchisement. Part VI concludes by speculating on the broader applicability of preliminary frames to other parts of the Constitution.

\section{THE Federal TAX EVAsion STATUTE}

The federal tax evasion statute, 26 USC $\$ 7201$, states that "[a]ny person who willfully attempts in any manner to evade or defeat any tax imposed by this title or the payment thereof shall ... be guilty of a felony." If $\S 7201$ punishes not the failure to pay tax but instead a criminal intent to "willfully" defraud the government, then felony tax evasion may fall out of the ambit of the Twenty-fourth Amendment, which proscribes the denial of the vote "by reason of failure to pay any poll tax or other tax." Such a reading of $\$ 7201$ eliminates any constitutional issues involving the Twenty-fourth Amendment."

\footnotetext{
Citizens: United States Territorial Residents and the Right to Vote in Presidential Elections, 1995 U Chi Legal F 315, 327-30 (arguing that income taxes are not "qualitatively different" from poll taxes).

11 See Crowell v Benson, 285 US 22, 62 (1932) (stating that statutes should be constructed to avoid constitutional questions if possible).
} 
Courts, however, have read the willfulness requirement of $\S 7201$ to interpose only a nominal mens rea between the nonpayment of taxes and a felony conviction. This limited mens rea indicates that the failure to pay tax constitutes the heart of the federal evasion felony-and forces the constitutional question.

Section 7201 describes three elements for the crime of tax evasion. First, a defendant must actually owe tax. ${ }^{12}$ Second, the defendant must have performed "an affirmative act constituting an evasion or attempted evasion of [that] tax." " Finally, the defendant must have acted "willfully." The Supreme Court has interpreted "willfully," as used in $\$ 7201$, to denote "a voluntary, intentional violation of a known legal duty." "evil intent," or proof of motive. ${ }^{16}$ Because "a voluntary, intentional violation" does not require a defendant's affirmative desire to deprive the government of tax receipts, the intent prong of the willfulness requirement essentially depends on mere knowledge of a tax obligation. If a defendant subjectively knows of a nonspecific legal duty to pay tax, any attempt to evade payment is voluntary and intentional. ${ }^{17}$ Substituting knowledge for intent essentially foregrounds the act of nonpayment at the expense of the specific intent not to pay.

Section 7201's actus reus requirement also indicates that the essence of tax evasion is the nonpayment of tax-not the willful intent to defraud the government. Just as courts have read only a minimal mens rea into $\S 7201$, the provision's "affirmative act" element captures almost any positive gesture that enables tax evasion. ${ }^{18}$ Indeed, the same circumstantial evidence may prove both the mens rea and

12 Sansone v United States, 380 US 343, 351 (1965).

13 Id.

14 Id. See also Ian M. Comisky, Lawrence S. Feld, and Steven M. Harris, 1 Tax Fraud and Evasion II 2.03[1] at 2-6 (Warren, Gorham \& Lamont 1995 \& Supp 2006).

15 Cheek v United States, 498 US 192, 201 (1991), citing United States v Pomponio, 429 US 10, 12 (1976) and United States $v$ Bishop, 412 US 346, 360 (1973). Note that "a bona fide misunderstanding" of tax law negates knowledge of a duty to pay. United States $v$ Murdock, 290 US 389,396 (1933).

16 Pomponio, 429 US at 12; Bishop, 412 US at 360.

17 See Cheek, 498 US at 202 ("[O]ne cannot be aware that the law imposes a duty upon him and yet be ignorant of it, misunderstand the law, or believe that the duty does not exist. In the end, the issue is whether ... the defendant was aware of the duty at issue."); Comisky, Feld, and Harris, 1 Tax Fraud I 2.03[3][b] at 2-25 (cited in note 14) (noting that knowledge may be imputed if the defendant has pursued "a conscious course of deliberate ignorance").

18 See Spies $v$ United States, 317 US 492, 495 (1943) (listing affirmative acts). See also Comisky, Feld, and Harris, 1 Tax Fraud and Evasion I 2.03[1] at 2-14 to -15 (cited in note 14). The failure to file a return normally does not represent an affirmative act. See Sansone, 380 US at 351-52. A taxpayer's failure to file, however, may be a felony if the return would include more than $\$ 10,000$ in cash receipts from a transaction (or a set of related transactions) performed in the course of a trade or business. 26 USC $\$ \S 6050 I(a), 7203$. 
the affirmative act for a single defendant..$^{19}$ Because $\S 7201$ 's mens rea and affirmative act elements are permissive, the requirement of tax due and owing stands as the core of $\S 7201$.

The presence of a distinct criminal tax fraud provision, 26 USC $\S 7206$, further bolsters the contention that nonpayment of tax is central to tax evasion under $\S 7201$. Section 7206 deems a felony the "mak[ing] or subscrib[ing of] any return, statement, or other document ... , which [the taxpayer] does not believe to be true and correct. ${ }^{20}$ Whether a defendant has paid tax does not bear on criminality under $\S 7206$; instead, the intent to defraud is central. ${ }^{21}$ If $\S 7201$ dealt centrally with a defendant's intent to defraud the government, then $\S 7201$ would cover essentially the same crimes as $\S 7206$, but with the additional element of tax due and owing. For $\S 7201$ and $\S 7206$ to describe distinct offenses, $\S 7201$ must depend heavily on the nonpayment of tax, the element that differentiates it from $\$ 7206$. Because the nonpayment of tax constitutes the core of $\S 7201$ tax evasion, a tension remains between the Twenty-fourth Amendment and disenfranchisement laws that include federal tax felons.

\section{THE CONSTITUTIONALITY OF TAX FELON DISENFRANCHISEMENT}

The Twenty-fourth Amendment notwithstanding, states may constitutionally deny the vote to federal tax felons. This Part argues that the Supreme Court has deemed felon disenfranchisement laws presumptively valid under the Fourteenth Amendment. Additionally, state and federal courts have indicated that income tax felonies are sufficient to trigger disenfranchisement. Only when a specific disenfranchisement statute violates the Equal Protection Clause's prohibition against racial discrimination have courts declared such statutes unconstitutional. Because tax felon disenfranchisement almost certainly does not reflect racial bias, such disenfranchisement laws are permissible under the Fourteenth Amendment's proscriptions-though not necessarily under the Twenty-fourth Amendment's strictures.

19 For example, keeping a double set of books or destroying records can adequately support a jury's determination of both actual knowledge and affirmative action. See Spies, 317 US at 499 . See also United States $v$ Pomponio, 563 F2d 659, 662-64 (4th Cir 1977) (upholding a tax evasion conviction based on the "informality" of financial arrangements that could have become fraudulent at some point in the future). See also Kenneth E. North, 2 Criminal Tax Fraud $\$ \S 16.31-.39$ at 57-66 (LEXIS 1998) (listing types of circumstantial evidence that adduce knowledge).

2026 USC $\$ 7206(1)$ (2000).

21 See id; Comisky, Feld, and Harris, 1 Tax Fraud \I 2.04[1] at 2-45 (cited in note 14). 


\section{A. Strict Scrutiny and Felon Disenfranchisement}

In Richardson $v$ Ramirez, ${ }^{22}$ the Supreme Court held that the Fourteenth Amendment grants an "affirmative sanction" to state criminal disenfranchisement laws. ${ }^{23}$ The three Ramirez plaintiffs, all convicted felons who had "completed the service of their respective sentences and paroles," challenged a California constitutional provision that categorically denied the franchise to both felons and exfelons. ${ }^{24}$ This provision reflected a tradition at both common and civil law that allowed governments to deem a convicted criminal "dead in law" and thus unable to perform "any legal function-including, of course, voting."25 The Ramirez Court explicitly considered the narrow issue of whether the Fourteenth Amendment abrogated the California constitution's disenfranchisement provision-and, by implication, whether that Amendment also vitiated the corollary rule at historical common law.

The Ramirez plaintiffs argued that California's felon disenfranchisement provisions denied them "the equal protection of the laws" in contravention of $\S 1$ of the Fourteenth Amendment. ${ }^{26}$ In prior decisions, the Court used the principle of one-person, one-vote to strictly scrutinize laws that restricted individuals' access to the ballot. ${ }^{27}$ To survive strict scrutiny, a voting regulation must be necessary to realize a compelling state interest and narrowly tailored to serve that interest. ${ }^{28}$

22418 US 24 (1974).

23 Id at 54 .

24 Id at 26-27.

25 Alec C. Ewald, "Civil Death": The Ideological Paradox of Criminal Disenfranchisement Law in the United States, 2002 Wis L Rev 1045, 1059-62 (noting, however, that European, English, and colonial American law did not preclude - and perhaps even anticipated - the reinstatement of an ex-felon's voting rights). See also Bell $v$ Wolfish, 441 US 520, $590 \mathrm{n} 22$ (1979) (Stevens dissenting) (describing felon disenfranchisement as "[t]he classic example of the coincidence of punishment and the total deprivation of rights"); Green $v$ Board of Elections, 380 F2d 445, 451 (2d Cir 1967) (Friendly) (recognizing states' "historic exclusion from the franchise of persons convicted of all or certain types of felonies"). See Keyssar, The Right to Vote at 302-08 (cited in note 8) (describing legal efforts between the 1960 s and 1990 s to curtail felon disenfranchisement).

26 See 418 US at 27 . See also US Const Amend XIV, § 1 ("No State shall ... deny to any person within its jurisdiction the equal protection of the laws.").

27 See, for example, Dunn v Blumstein, 405 US 330, 342-43 (1972) (evaluating voting laws "by a strict equal protection test"); Kramer v Union Free School District, 395 US 621, 626 (1969) (calling for "close scrutiny" of statutes, "which may dilute the effectiveness of some citizens" votes"); Reynolds $v$ Sims, 377 US 533, 562 (1964) ("[A]ny alleged infringement of the right of citizens to vote must be carefully and meticulously scrutinized.").

28 See Blumstein, 405 US at 337 (noting that to survive strict scrutiny laws must be "necessary to promote a compelling governmental interest"); Kramer, 395 US at 627 ("[I]f a challenged state statute grants the right to vote to some bona fide residents ... and denies the franchise to others, the Court must determine whether the exclusions are necessary to promote a compelling state interest."). See also Keyssar, The Right to Vote at 304-06 (cited in note 8) (discussing lower courts' interpretations of Blumstein that led to the Ramirez challenge). 
The Ramirez plaintiffs claimed that no compelling state interest justified the exclusion of ex-felons from voter rolls. ${ }^{29}$

Writing for the Court in Ramirez, Justice Rehnquist rejected the plaintiffs' equal protection arguments and declined to apply strict scrutiny to the disenfranchisement provision. ${ }^{30}$ Instead of relying on only the Equal Protection Clause in $\S 1$ of the Fourteenth Amendment, Rehnquist considered the Amendment holistically. Section 2 of the Fourteenth Amendment requires that "when the right to vote at any election ... is denied to any of the male inhabitants of [a] state,... or in any way abridged, [that state's] basis of representation [ ] shall be [proportionately] reduced." ${ }^{31}$ Section 2, however, permits states to disenfranchise without penalty two classes of individuals: those who "participat[e] in rebellion" and those who commit some "other crime." ${ }^{32}$ Justice Rehnquist explained that:

[T] he exclusion of felons from the vote has an affirmative sanction in $\S 2$ of the Fourteenth Amendment .... [Section] 1, in dealing with voting rights as it does, could not have been meant to bar outright a form of disenfranchisement which was expressly exempted from the less drastic sanction of reduced representation which $\S 2$ imposed for other forms of disenfranchisement. ${ }^{33}$

Rehnquist surmised that, for all of the language in $\S 2$ to have meaningful effect, $\S 1$ could not categorically preclude states from disenfranchising felons. ${ }^{34}$ Not only are felon disenfranchisement laws

29 See 418 US at 33. Not only did Blumstein, Kramer, and Sims indicate that the Court might sympathize with a Fourteenth Amendment challenge to felon disenfranchisement laws, but earlier Court opinions made alternative constitutional claims under the Eighth Amendment unattractive. See, for example, Trop v Dulles, 356 US 86, 96-97 (1958) (describing disenfranchisement laws "as a nonpenal exercise of the power to regulate the franchise"). See also US Const Amend VIII (prohibiting "cruel and unusual punishments"). See generally Pamela A. Wilkins, The Mark of Cain: Disenfranchised Felons and the Constitutional No Man's Land, 56 Syracuse L Rev 85 (2005) (arguing that disenfranchisement must be viewed as a distinct punishment and evaluated under the Eighth Amendment).

30 See 418 US at 54.

31 US Const Amend XIV, $\$ 2$.

32 Id; Ramirez, 418 US at 53-54.

33 Ramirez, 418 US at 54-55. See also Green, 380 F2d at 451 (Friendly) ("[T]he propriety of excluding felons from the franchise has been [] frequently recognized.").

34 Consider Holmes v Jennison, 39 US 540, 570-71 (1840) ("[E]very word [in the Constitution] must have due force and appropriate meaning, for it is evident from the whole instrument that no word was unnecessarily used or needlessly added."). Lower courts had previously applied similar textual arguments to facts analogous to Ramirez. See, for example, Otsuka v Hite, $64 \mathrm{Cal}$ 2d 596, 414 P2d 412, 426 (1966) (Burke dissenting) (interpreting $\$ 2$ similarly); Fincher v Scott, 352 F Supp 117, 119 (MD NC 1972) (same). Scholars, however, have largely rebuked Rehnquist's rigid textualism. See, for example, Ewald, 2002 Wis L Rev at 1066 (cited in note 25) ("[Ramirez] frustrates attempts to understand the ideological principles behind American criminal disenfranchisement, because the Court made a quintessentially 'textual' decision in eschewing serious 
expressly permitted by the Fourteenth Amendment, but, unlike other restrictions on voting rights, such laws do not face strict judicial scrutiny.

\section{B. Disenfranchisement and Tax Felonies}

By holding that the Fourteenth Amendment's text permits felon disenfranchisement laws, the Ramirez Court effectively granted the states broad latitude to determine the specific substance of such laws. Picking whether (and which) felons should vote amounts to "choos[ing] one set of values over [an]other," and this choice is, in Rehnquist's view, best "addressed to the legislative forum," which can "properly weigh and balance" all competing considerations. ${ }^{35}$ But there are limits to this legislative deference. First, lower courts subject disenfranchisement provisions to rational basis review. Second, substantive constraints exist. Ramirez discusses only felonies and infamous crimes, which are both terms of art used in state disenfranchisement provisions, and these categories imply an endogenous limit to the strict scrutiny exception effected by $\S 2 .^{36}$ Third, the Supreme Court has discerned a carve-out to the Ramirez rule if states enact disenfranchisement laws with a racially discriminatory purpose. Notwithstanding these constraints, federal tax felonies almost certainly remain valid triggering offenses for state disenfranchisement provisions.

\section{Rational basis review.}

In the wake of Ramirez, lower courts have analyzed the content of felon disenfranchisement laws using a rational basis test. ${ }^{37}$ Such

attention to political theory, broad Constitutional principles, or social norms."). See also Gabriel J. Chin, Reconstruction, Felon Disenfranchisement, and the Right to Vote: Did the Fifteenth Amendment Repeal Section 2 of the Fourteenth Amendment?, 92 Georgetown L J 259, 263, 313-14 (2004) (arguing that the Fifteenth Amendment invalidated $\S 2$ of the Fourteenth Amendment, which moots the textual rationale of Ramirez).

35 Ramirez, 418 US at 55 (positing that if one position "is indeed the more enlightened and sensible one, presumably the people of the State of California will ultimately come around to that view"). Indeed, in the time between the Ramirez decision and the California Supreme Court's hearing on remand, the California constitutional provision was amended to disenfranchise felons only while imprisoned or on parole. Ramirez v Brown, 12 Cal 3d 912, 528 P2d 378, 379 (1974) (Mosk) ("The issue which is the subject of the United States Supreme Court mandate in this case is therefore moot."). See also Keyssar, The Right to Vote at 306 \& $n 94$ (cited in note 8) (noting that, notwithstanding this legislative action, Ramirez still "effectively closed the door on equal protection challenges to the disenfranchisement of criminals").

36 See Ramirez, 418 US at 48 (noting that, at the Fourteenth Amendment's ratification, twenty-nine states had constitutional provisions that "prohibited, or authorized the legislature to prohibit, exercise of the franchise by persons convicted of felonies or infamous crimes").

37 See Woodruff $v$ Wyoming, 49 Fed Appx 199, 203 (10th Cir 2002) (finding frivolous two inmates' claims, brought in a pro se suit, that disenfranchisement violated equal protection principles); Baker v Cuomo, 58 F3d 814, 820-21 (2d Cir 1995) (upholding a statute that disenfranchised only incarcerated felons), reheard en banc as Baker v Pataki, 85 F3d 919 (1996) (affirming 
laws are "accorded a strong presumption of validity," and they "cannot run afoul of the Equal Protection Clause if there is a rational relationship between disparity of treatment and some legitimate governmental purpose." 38 This Part argues that courts will almost certainly uphold tax felon disenfranchisement, even if other types of felons retain their voting rights, because tax felonies implicate behavior that courts have found incompatible with core values associated with the franchise.

In two ways, the disenfranchisement of tax felons safeguards "the purity of the ballot box," a judge-constructed concept deemed by courts to represent a legitimate state interest. ${ }^{39}$ First, tax felons' votes may dilute the votes of law-abiding citizens. Because the Supreme Court has deemed tax evasion a crime of moral turpitude, ${ }^{40}$ the presumptive risk of voter fraud, manipulation, or disingenuousness - and thus the threat to civic republican values-runs particularly high among tax offenders.' Second, tax felons may have paradigmatically

by a divided panel the earlier constitutional claims of the trial court); Owens $v$ Barnes, 711 F2d 25, 27 (3d Cir 1983) (" $[\mathrm{T}]$ he state can not only disenfranchise all convicted felons but it can also distinguish among them provided that such distinction is rationally related to a legitimate state interest."); Williams v Taylor, 677 F2d 510, 514 (5th Cir 1982) ("[The] classification of felons for voting restrictions must bear only a rational relation to the achieving of a legitimate state interest."); Shepherd $v$ Trevino, 575 F2d 1110, 1115 (5th Cir 1978) (finding a rational basis for disenfranchisement laws that allowed state and not federal felons to apply for re-enfranchisement). See also United States v Arce, 997 F2d 1123, 1127 (5th Cir 1993) (applying the rational basis test to laws precluding felons from jury service); Wesley $v$ Collins, 791 F2d 1255, 1261-62 (6th Cir 1986) (finding that "the state's legitimate and compelling rationale" for felon disenfranchisement laws precluded a challenge under the Voting Rights Act of 1965).

38 Heller v Doe, 509 US 312,319-20 (1993). See also Williamson v Lee Optical, 348 US 483, 488 (1955) ("It is enough that there is an evil at hand for correction, and that it might be thought that the particular legislative measure was a rational way to correct it.").

39 See Washington v State, 75 Ala 582, 585 (1884). See also Hobson v Pow, 434 F Supp 362, 366 (ND Ala 1977) ("The State's interest in preserving the 'purity' of the franchise may allow it to exclude all felons."). Although courts and commentators have critiqued the factual basis for arguments favoring "the purity of the ballot box," see, for example, Dillenburg $v$ Kramer, 469 F2d 1222, 1224 (9th Cir 1972) (describing the "preservation of 'the purity of the ballot box"” as "a quasi-metaphysical invocation"); Note, The Disenfranchisement of Ex-Felons: Citizenship, Criminality, and 'The Purity of the Ballot Box,' 102 Harv L Rev 1300, 1304-09 (1989) (identifying weaknesses in contractarian and civic republican justifications for felon disenfranchisement), courts continue to acknowledge the validity of this government purpose. See, for example, Burson $v$ Freeman, 504 US 191, 221 (1992) (Stevens dissenting) (recognizing the "purity of the ballot box" as a state interest but arguing that it is not a compelling one).

40 See Jordan v DeGeorge, 341 US 223, 232 (1951) (holding that federal tax felonies are crimes of moral turpitude because they involve fraud). Although subsequent cases have minimized the fraud component of tax evasion, see Part I, the Court's classification will likely stand because of both stare decisis and the modicum of fraud implicit in the offense.

41 See Wesley, 791 F2d at 1261-62 ("[I]t can scarcely be deemed unreasonable for a state to decide that perpetrators of serious crimes shall not take part in electing the legislators who make the laws, the executives who enforce these, the prosecutors who must try them for further violations, or the judges who are to consider their cases."), quoting Green, 380 F2d at 451 (Friendly). This rationale tracks two of the four reasons for disenfranchisement rejected by Note, 102 Harv L Rev at $1303,1307-09$ (cited in note 39): "to guard against voter fraud" and to ensure "moral competence." 
violated judicial constructions of the social contract. On this version of social contract, the state is not obligated to respect the rights of those that undermine the state's ability to maintain the social contract. ${ }^{42}$ By promoting both classical liberal and civic republican political purposes, tax felon disenfranchisement represents a reasonable means to eliminate "threat[s] to the integrity of the elective process."

State disenfranchisement provisions most likely also survive heightened rational basis review, or "rational basis with bite." heightened rational basis review, courts weigh a state's explicitly asserted interests (as opposed to possible interests) against the harms those provisions wreak on the rights of individuals from groups "approaching quasi-suspect status." $"$ In the case of tax felon disenfranchisement, states' asserted "purity of the ballot box" rationales for enacting disenfranchisement provisions match the best possible justification under ordinary rational basis review. Heightened rational basis review therefore collapses into ordinary rational basis review, and the outcome-favoring the state-will almost certainly be the same. This situation differs markedly from canonical heightened rational basis cases in which the Court deemed the government's asserted interests spurious and tangential to the rights infringed. ${ }^{46}$ In addition, tax felons, as a group, do not approach quasi-suspect status. Under a contractarian theory of disenfranchisement, citizens become felons through elective criminal acts that directly (and justly) implicate the abrogation of political rights. Unlike laws parsing individuals based on disability, citizenship, or sexual orientation, tax felon disenfranchise-

42 See Green, 380 F2d at 451 (positing that felons violate the Lockean social contract). This rationale tracks the other two reasons for disenfranchisement rejected by Note, 102 Harv L Rev at 1302, 1304-07 (cited in note 39): to prevent felons from "alter[ing] the content or administration of the criminal law" and to preserve the integrity of "the social contract."

43 See Otsuka, $414 \mathrm{P} 2 \mathrm{~d}$ at 422.

44 See Gayle Lynn Pettinga, Note, Rational Basis with Bite: Intermediate Scrutiny by Any Other Name, 62 Ind L J 779, 779-80 (1987) (characterizing "rational basis with bite" as "simply intermediate scrutiny without an articulation of the factors that triggered it").

45 See id at 785, 794-95. See also Romer $v$ Evans, 517 US 620, 635 (1996) (examining the government's proffered reasons for a state constitutional amendment that prohibited "particular [legal] protections" for homosexuals and determining that those reasons did not suffice under rational basis review); Cleburne v Cleburne Living Center, 473 US 432, 446-47, 448-50 (1985) (abrogating a zoning ordinance that "rest[ed] on an irrational prejudice against the mentally retarded" after dismissing the municipality's reasons for the ordinance); Plyler v Doe, 457 US 202, 227-30 (1982) (finding that the alleged government interests failed to provide a rational basis for a statute denying public education to illegal alien children).

46 See Romer, 517 US at 635 ("The breadth of the [state constitutional] Amendment is so far removed from these particular justifications that we find it impossible to credit them."); Cleburne, 473 US at 450 (noting that the municipality's stated "concerns obviously fail[ed] to explain" the differential permitting scheme applied to homes for the "mentally retarded"); Plyler, 457 US at 230 ("It is difficult to understand precisely what the State hopes to achieve by promoting the creation and perpetuation of a subclass of illiterates within our boundaries."). 
ment provisions demonstrate a direct link between the status-creating trigger and the differential treatment. ${ }^{47}$ Under either ordinary or heightened rational basis review, courts will almost certainly find the disenfranchisement of tax felons constitutional.

An alternate rational basis challenge to the substance of felon disenfranchisement laws involves whether those laws are overinclusive to the point of absurdity. ${ }^{48}$ Writing in dissent in Ramirez, Justice Marshall observed that seemingly minor crimes, such as "seduction under promise of marriage, or conspiracy to operate a motor vehicle without a muffler," qualified as state law felonies. For these offenses to warrant the permanent revocation of an individual's voting rights was simply absurd, Marshall argued. .9 $^{4}$ Four years before Ramirez, a New Jersey federal district court could "perceive no rational basis" in a similarly "irrational and inconsistent classification." "Tax felons, however, lack standing to bring this type of claim. Because tax felonies illustrate a paradigmatic situation in which a legitimate state interest supports the prerogative to disenfranchise, tax felons are not harmed by disenfranchisement provisions irrational with respect to other, less egregious offenses. ${ }^{51}$ Were these absurd provisions remedied, tax felo-

47 See Romer, 517 US at 635 (homosexuals); Cleburne, 473 US at 450 (the "mentally retarded"); Plyler, 457 US at 205 (aliens).

48 See Ramirez, 418 US at 75 n 24 (Marshall dissenting) (arguing that the Ramirez majority would allow "[e]ven a jaywalking or traffic conviction ... [to constitutionally] lead to disenfranchisement"). See also Church of the Holy Trinity v United States, 143 US 457, 460 (1892) (stating the absurdity doctrine as it applies to statutory construction). But consider states' success in promulgating categorical and overinclusive statutes banning felons from possessing firearms, as described in Adam Winkler, The Reasonable Right to Bear Arms, 17 Stan L \& Policy Rev 597, 603-04 (2006) ("Every state court to rule on a felon possession ban in the modern era-and the cases are numerous-has held that such laws are reasonable."); Jeffrey Monks, Comment, The End of Gun Control or Protection against Tyranny?: The Impact of the New Wisconsin Constitutional Right to Bear Arms on State Gun Control Laws, 2001 Wis L Rev 249, 261 \& n 77 (collecting state court cases). See also id at 278 (noting arguments that a proposed Wisconsin constitutional amendment granting an expansive "right to bear arms" would not abrogate existing Wisconsin statutes prohibiting felon gun possession).

49 Ramirez, 418 US at 75 n 24 (Marshall dissenting), citing Otsuka, 414 P2d at 418 (Mosk) ("The unreasonableness of a classification disfranchising all former felons, regardless of their crime, is readily demonstrable.").

50 Stephens $v$ Yeomans, 327 F Supp 1182, 1188 (D NJ 1970) (noting with opprobrium that under New Jersey law "[m]ost defrauders, including persons convicted of income tax fraud, remain eligible to vote"). See also Dillenburg, 469 F2d at 1225 (finding that offenses that trigger disenfranchisement "do not follow any perceivable pattern," but applying strict scrutiny to the classifications); Butts $v$ Nichols, 381 F Supp 573, 580-82 \& n 10 (DC Iowa 1974) (invalidating a statute that barred felons from municipal employment because it created "a totally irrational and inconsistent scheme"); Hobson, 434 F Supp at 366 (contending that no "rational reason" existed "to support the exclusion of wife beaters, while not excluding others convicted of assault and battery").

51 See United States v Raines, 362 US 17, 21 (1960) ("[O]ne to whom application of a statute is constitutional will not be heard to attack the statute on the ground that impliedly it might also be taken as applying to other persons or other situations in which its application might be unconstitutional."). 
nies still would fall within the realm of permissible disenfranchising infractions. Tax felonies represent the core, rather than the fringe, of crimes that warrant disenfranchisement, and therefore they are illsuited to challenges grounded in the absurdity of particular disenfranchisement provisions.

\section{Felonies and infamous crimes.}

Two substantive limits affect the scope of the strict scrutiny exception crafted by Rehnquist in Ramirez. First, Rehnquist posits that the Fourteenth Amendment explicitly contemplates "the exclusion of felons from the vote. ${ }^{, 2}$ Second, Ramirez upheld a state constitutional provision that authorized the disenfranchisement of individuals "convicted of an infamous crime." ${ }^{\text {,53 }}$ By implication, only triggering offenses that are felonies or infamous crimes benefit from the strict scrutiny exception. ${ }^{54}$ Offenses that are neither felonies nor infamous crimes must survive a "fatal in fact" inquisition into the state interest behind the abrogation of the offender's fundamental voting rights.

The catalogue of felony offenses is defined by either a crime's statutory designation or its status at common law, or both. ${ }^{56}$ The spe-

52 Ramirez, 418 US at 54. Blackstone offers additional textual support for the interpretation of "other crimes" as referring to felonies. Quoting Coke, Blackstone notes that rebellion against government historically represented the quintessential felony. Williams Blackstone, 4 Commentaries on the Laws of England *94-95 (Chicago 1979). If "participation in rebellion" is paradigmatic of the class of "other crime[s]," then those other crimes are almost certainly felonies. Similarly, Blackstone lists "crimes and misdemeanors" as the two distinct categories of criminality. See id at *1, 5 . Therefore, "crimes" may be synonymous with felonies.

53418 US at 27 (quotation marks omitted).

54 See McLaughlin v City of Canton, 947 F Supp 954, 975 (SD Miss 1995) (applying strict scrutiny to a state constitutional provision disenfranchising misdemeanants); Hobson, $434 \mathrm{~F}$ Supp at 366 ("The State's interest in preserving the 'purity' of the franchise may allow it to exclude all felons, but exclusion of some, but not all, of a subject category of persons (here, misdemeanants) must be supported by a compelling state interest.") (citation omitted). But see Owens, 711 F2d at 27 (disapproving of Hobson). The Supreme Court has left open the issue of whether certain minor, malum prohibitum criminal acts, such as "moral turpitude misdemeanors," warrant strict scrutiny. See Hunter $v$ Underwood, 471 US 222, 233 (1985) (abrogating an Alabama disenfranchisement statute on the grounds that its original adoption in 1901 was racially motivated).

55 See Gerald Gunther, The Supreme Court, 1971 Term-Foreword: In Search of Evolving Doctrine on a Changing Court: A Model for a Newer Equal Protection, 86 Harv L Rev 1, 8 (1972) (describing "a rigid two-tier attitude" toward equal protection in which strict scrutiny leads to abrogation and rational basis review leads to approbation). But see Adarand Constructors $v$ Pena, 515 US 200, 237 (1995) ("[W]e wish to dispel the notion that strict scrutiny is "strict in theory, but fatal in fact."); Adam Winkler, Fatal in Theory and Strict in Fact: An Empirical Analy. sis of Strict Scrutiny in the Federal Courts, 59 Vand L Rev 793, 796 (2006) (claiming that one-third of statutes survive strict scrutiny in federal courts).

56 See Wayne R. LaFave, Criminal Law § 1.6(a) at 34-36 (West 4th ed 2003) (describing the interplay between statutory and common law in the scope of felony crimes). The term "felony" is notoriously hard to define. See Lynch v Commonwealth, $88 \mathrm{~Pa} 189,192$ (1879) ("Felony, as a term, is incapable of any definition, and is descriptive of no offence."). This definitional issue 
cific facts in Ramirez indicate that the decision's strict scrutiny exception applies to statutory as well as common law felonies. ${ }^{57}$ Of the three Ramirez plaintiffs, one was disenfranchised because of a conviction for heroin possession, a purely statutory felony. ${ }^{58}$ The crimes of the other two Ramirez plaintiffs were robbery by assault, burglary, and forgery - all traditional common law felonies. ${ }^{59}$ Because Rehnquist's holding does not differentiate between the three plaintiffs by crime, the strict scrutiny exception established by Ramirez must encompass statutory felonies as well as common law felonies. This less restrictive definition of felony also comports with historical understandings of American criminal law as principally statutory and secondarily rooted in the common law. ${ }^{60}$ Although tax evasion lacks a common law predicate, ${ }^{61}$ it falls under the Ramirez strict scrutiny exception because Congress has designated it a statutory felony.

Even were tax evasion not a Fourteenth Amendment "felony," it qualifies for the Ramirez strict scrutiny exception as an "infamous crime" under either of the two predominant judicial understandings of the term. First, infamous crimes are those that warrant incarceration in the penitentiary, regardless of whether a particular defendant actually served time. ${ }^{63}$ Rehnquist cites congressional floor debates about the Fourteenth Amendment that support this interpretation, including an Ohio Representative who noted in 1866 that "persons convicted of

stems in part from the tangled history of English criminal law, in which statutes and the common law developed in tandem. See Douglas Hay, Property, Authority and the Criminal Law, in Douglas Hay, et al, eds, Albion's Fatal Tree 17, 18 (Pantheon 1975) (describing the burgeoning number of criminal statutes in eighteenth-century England).

57 Although Rehnquist cites the post-Civil War enabling acts, which re-admitted the former Confederate states to the Union, as permitting disenfranchisement "as a punishment for such crimes as [were then] felonies at common law," Ramirez, 418 US at 51, this statement merely establishes historical practice and does not limit the holding to common law felonies.

58 See 418 US at 32 n 9; John R. Cosgrove, Four New Arguments against the Constitutionality of Felon Disenfranchisement, $26 \mathrm{~T}$ Jefferson L Rev 157, 159 (2004).

59 See 418 US at 32 n 9; Blackstone, 4 Commentaries at *95, 97, 98-99 (cited in note 52).

60 See Joel Prentiss Bishop, 1 Bishop on Criminal Law $\$ 616$ at 447-48 (John M. Zane and Carl Zollman, eds) (Chicago 1923) ("[T]he term 'felony' at the present day, simply denotes the degree or class of crime committed.").

61 See Keenan v McGuane, 13 Ill 2d 520, 150 NE2d 168, 177 (1958) ("[A]t common law there was no such offense as income tax evasion."). See also United States v Henry, 26 F Cas 274, 274 (SDNY 1868) ("[Evasion of excise taxes] was not an offence at common law."); Cosgrove, 26 T Jefferson L Rev at 159 (cited in note 58) (arguing that Ramirez does not apply "to disenfranchisement for statutory offenses not recognized as felonies at common law").

62 See 26 USC $\$ 7201$.

63 See In re Claasen, 140 US 200, 204-05 (1891) ("[I]n determining whether the crime is infamous, the question is whether it is one for which the statute authorizes the court to award an infamous punishment, and not whether the punishment ultimately awarded is an infamous one."); Merritt v Jones, 259 Ark 380, 533 SW2d 497, 500 (1976) ("It is not material [to whether a crime is a felony] that Appellee was not in fact sentenced to a term in the penitentiary and did not in fact serve any time."). 
a crime against the laws of the United States, the penalty for which is imprisonment in the penitentiary, are now and always have been disfranchised." ${ }^{64}$ Federal income tax evasion garners a maximum penitentiary sentence of five years, ${ }^{65}$ and therefore it qualifies as an infamous crime under this first definition.

A second judicial interpretation defines an "infamous crime" as a "felony ... within the general classification of being inconsistent with commonly accepted principles of honesty and decency, or which involves moral turpitude." ${ }^{, 66}$ This definition reflects the common law definition of infamous crimes in 1870 , just two years after the ratification of the Fourteenth Amendment. ${ }^{67}$ Because federal income tax evasion is both a statutory felony and a crime of moral turpitude, ${ }^{68}$ it is also an infamous crime under this second definition. As a statutory felony and an infamous crime, tax evasion falls into the strict scrutiny exception created by Ramirez.

3. Strict scrutiny and race.

Although Ramirez removes felon disenfranchisement laws from the heightened judicial scrutiny ordinarily accorded laws that limit voting rights, ${ }^{69}$ the decision does not foreclose strict scrutiny for those disenfranchisement laws that target a particular suspect class. In Hunter $v$ Underwood, ${ }^{70}$ the Court found felon disenfranchisement laws void if they have the purpose of furthering discrimination on the basis of race. ${ }^{7}$ Lower courts, however, have read this exception narrowly,

64 Ramirez, 418 US at 46, quoting Rep Eckley, Cong Globe, 39th Cong, 1st Sess 2535 (1866).

6526 USC $\$ 7201$. Some state courts refuse to extend "infamous crime" disenfranchisement provisions to crimes punishable by hard time in a prison other than that state's penitentiary. See, for example, People v Enlow, 135 Colo 249, 310 P2d 539, 546-47 (1957) (holding that federal income tax evasion is not an "infamous" crime because it is not punishable in Colorado's state penitentiary). See also Tucker $v$ Huval, 374 So $2 \mathrm{~d}$ 745, 748 (3d Cir 1979) (preventing a federal tax felon's removal from public office because income tax evasion was not a felony under state law). See generally Cosgrove, 26 T Jefferson L Rev 157 (cited in note 58). Other state courts have upheld the curtailment of political rights for felons convicted in other jurisdictions. See Peach v Goins, 575 SW2d 175, 179-80 (Mo 1978) (holding that convictions in other jurisdictions that would be felonies in the state are sufficient for removal from state office); Arpagaus $v$ Todd, 29 NW2d 810, 812 (Minn 1947) (same). See also Bruno v Murdock, 406 SW2d 294, 297 (Mo App 1966) (upholding plaintiff's felony disenfranchisement even though income tax evasion was merely a misdemeanor at state law); Barrett v Sartorius, 351 Mo 1237, 175 SW2d 787, 790 (1943) (same).

66 Keenan, 150 NE2d at 176.

67 See id.

68 See Part 1.B.2; note 40 and accompanying text.

69 See Allen $v$ Ellisor, 664 F2d 391, 395 (4th Cir 1981) ("The decision in Richardson is generally recognized as having closed the door on the equal protection argument in a challenge to state statutory voting disqualifications for conviction of crime.").

70471 US 222 (1985).

71 Id at $232-35$. 
leaving intact a strong presumption of constitutionality for felon disenfranchisement statutes."

In Hunter, the Court reviewed the constitutionality of an Alabama disenfranchisement provision that allegedly affected blacks more than whites. Justice Rehnquist, writing for the majority, employed the same holistic interpretive scheme that he used in Ramirez. Reading $\S \S 1$ and 2 of the Fourteenth Amendment in tandem, Rehnquist stated that " $\S 2$ was not designed to permit [ ] purposeful racial discrimination ... which otherwise violates $\S 1 .{ }^{\prime \prime 3}$ In Ramirez, $\S 2$ restricted the application of $\S 1$; in Hunter, $\S 1$ limited the scope of $\S 2$. Because the Alabama disenfranchisement provision's triggering offenses included some petty and serious crimes "thought to be more commonly committed by blacks," such as "vagrancy, living in adultery, and wife beating," Rehnquist deemed the provision "original[ly] enact[ed] ... to discriminate against blacks on account of race" and therefore unconstitutional. ${ }^{74}$ Not only did Hunter delineate the outer bounds of states' discretion to disenfranchise felons, but the decision also made explicit a connection between a disenfranchisement law's triggering offenses and the legitimacy of that law's purpose.

72 Indeed, this strong presumption of constitutionality may even preclude plaintiffs from challenging state disenfranchisement laws under federal statutes such as the Voting Rights Act (VRA), 42 USC $\$ 1973$ (2000). Compare Johnson v Bush, 405 F3d 1214, 1234 (11th Cir 2005) (arguing that allowing a challenge to felon disenfranchisement laws under the VRA would force "a reading of the statute which would prohibit a practice that the Fourteenth Amendment permits [states] to maintain"), cert denied, 546 US 1015 (2005); Muntaqim v Coombe, 366 F3d 102, 104 (2d Cir 2004) (holding that applying the VRA to New York's felon disenfranchisement statute would "alter the constitutional balance between the states and the federal government" and that no "clear statement from Congress" supports such an application), vacated by Muntaqim v Coombe, 449 F3d 371, 374 (2d Cir 2006) (holding that Muntaqim lacked standing to pursue his claim), with Farrakhan $v$ Washington, 338 F3d 1009, 1011-12 (9th Cir 2003) (finding a cause of action under the VRA even though the felon disenfranchisement statute was not inherently discriminatory because the statute "interact[ed] with external factors such as [discrimination in the criminal justice system] to result in denial of the right to vote on account of race or color") (emphasis omitted), rehearing en banc denied 359 F3d 1116, 1116-17, 1123 (9th Cir 2004) (Kozinski dissenting) (arguing that the Ninth Circuit's "expansive reading" of the VRA threatens the law's constitutionality and "lays the groundwork for the dismantling of the most important piece of civil rights legislation since Reconstruction"); Wesley, 791 F2d at 1259-61 (assuming that felon disenfranchisement laws may be challenged under the VRA but finding no violation in the instant case). See generally Baker v Pataki, 85 F3d 919 (2d Cir 1996) (en banc) (presenting, in a nonprecedential 5-5 decision, arguments on both sides of the debate); Keyssar, The Right to Vote (cited in note 8) (describing the genesis of this legal strategy in the 1990s); Lauren Handelsman, Note, Giving the Barking Dog a Bite: Challenging Felon Disenfranchisement under the Voting Rights Act of 1965, 73 Fordham L Rev 1875 (2005) (discussing state felon disenfranchisement laws in the context of the VRA); Andrew L. Shapiro, Note, Challenging Criminal Disenfranchisement under the Voting Rights Act: A New Strategy, 103 Yale L J 537 (1993) (same).

73 Hunter, 471 US at 233.

74 See id at 232-33 (8-0 decision). 
Lower courts, however, have interpreted Hunter as a principally procedural prohibition, and the deferential review advocated in Ramirez dominates courts' analysis of the substance of disenfranchisement laws. ${ }^{75}$ For a disenfranchisement law to be deemed unconstitutional under Hunter, its history must display a clear legislative "intent to discriminate," and that forbidden intent must have altered the law's substance. ${ }^{76}$ Whether a disenfranchisement provision in practice produces racially disparate results does not affect its constitutionality. ${ }^{7}$ This distinction between iniquitous enactment and discriminatory effect appears starkest in the context of legislative re-enactments of racially motivated felon disenfranchisement provisions. The Fifth and Eleventh Circuits have held that such re-enactments, if well-deliberated and racially unbiased, overcome Hunter's intent test, regardless of any enduring racially disproportionate impact. ${ }^{78}$ The substance of the disenfranchisement provision may remain unchanged, as long as the formal procedures under which it was enacted no longer reflect racial bias. ${ }^{79}$ Re-enactment therefore offers a means for state lawmakers to immunize state disenfranchisement provisions, in their entirety and at once, from invalidation under Hunter. In addition, the current federal tax felon statute, like these immunized state provisions, was enacted without discriminatory intent. ${ }^{80}$ Whether challenged under Hunter's exception to Ramirez, rational basis review, or the conceptual limits of the Ramirez exemption, the disenfranchisement of federal tax felons is constitutional under the Fourteenth Amendment.

75 Rehnquist explicitly states that the Hunter exception does not reopen the conclusions of Ramirez. See id at 233.

76 See, for example, Wesley, 791 F2d at 1262 n 10 (conducting a "review of the legislative debates surrounding the enactment of [a] challenged Tennessee statute" and finding no discriminatory intent). See also McLaughlin, $947 \mathrm{~F}$ Supp at 976-78 (citing academic and judicial analysis of the legislative history of Mississippi's disenfranchisement provisions).

77 See Rogers $v$ Lodge, 458 US 613, 617 (1982) (holding that "multimember districts violate the Fourteenth Amendment if 'conceived or operated as purposeful devices to further racial discrimination"); Arlington Heights v Metropolitan Housing Corp, 429 US 252, 265 (1977) ("Proof of racially discriminatory intent or purpose [and not simply disparate impact] is required to show a violation of the Equal Protection Clause."); Washington v Davis, 426 US 229, 240 (1976) ("[T]he invidious quality of a law claimed to be racially discriminatory must ultimately be traced to a racially discriminatory purpose.").

78 See Johnson, 405 F3d at 1220-21 (implying that a 1968 state constitutional revision purged any discriminatory intent left from an 1868 version); Cotton v Fordice, 157 F3d 388, 391 (5th Cir 1988) ("[E]ach amendment superseded the previous provision and removed the discriminatory taint associated with the original version.").

79 Cotton, $157 \mathrm{~F} 3 \mathrm{~d}$ at 391.

80 See generally HR Rep No 83-1337, 83d Cong, 2d Sess (1954), reprinted in 1954 USCCAN 4017 (showing no discriminatory intent in drafting the tax evasion provisions of the Internal Revenue Act of 1954); S Rep No 83-1622, 83d Cong, 2d Sess (1954), reprinted in 1954 USCCAN 4621 (same). 


\section{THE NARROW AND BROAD TWENTY-FOURTH AMENDMENT}

Courts have interpreted the Twenty-fourth Amendment to be simultaneously narrow and broad. The Amendment applies only to a narrow band of federal elections, namely "any primary or other election for President or Vice President, for electors for President or Vice President, or for Senator or Representative in Congress." ${ }^{81}$ But the Amendment's guarantee - that citizens' voting rights "shall not be denied or abridged by the United States or any state by reason of failure to pay any poll tax or other tax" ${ }^{\prime 82}$-is broad and categorical. Despite states' latitude under the Fourteenth Amendment to sculpt felon disenfranchisement laws, any curtailment of voting rights caused by a "failure to pay any poll tax or other tax" will fall under the Twentyfourth Amendment's guarantee. In a direct conflict between the Fourteenth and Twenty-fourth Amendments, the Twenty-fourth, as the later in time, will prevail.

\section{A. Narrowness}

The Supreme Court has implicitly constructed the Twenty-fourth Amendment narrowly by reading the Fourteenth Amendment broadly. By its text, the Twenty-fourth Amendment affects only federal elections. ${ }^{84}$ The Supreme Court somewhat quixotically confirmed this interpretation in Harper $v$ Virginia Board of Education, ${ }^{85}$ which the Court decided less than two years after the states ratified the Twentyfourth Amendment. ${ }^{86}$ Writing for the Harper majority, Justice Douglas held that state election poll taxes, no matter how nominal, are unconstitutional under the Fourteenth Amendment's Equal Protection Clause. ${ }^{87}$ Economic means - an ability to pay the poll tax-cannot de-

81 US Const Amend XXIV, § 1. See also Faubus v Miles, 237 Ark 957, 377 SW2d 601, 604 (1964) (finding "no merit" to arguments that the Twenty-fourth Amendment "abolishe[d] the poll tax as a prerequisite to voting in state elections").

82 US Const Amend XXIV, $\$ 1$.

83 Compare US Const Amend XIX, $\S 1$ (extending, in 1919, the franchise to women); US Const Amend XXVI, $\$ 1$ (guaranteeing, in 1971, the right to vote to U.S. citizens "who are eighteen years of age or older"), with US Const Amend XIV, $\$ 2$ (reducing states' representation for "den[ying the right to vote] to any of the male inhabitants of [a] state, being twenty-one years of age").

84 The enactment of the Voting Rights Act of 1965, which prohibited poll taxes in state elections, supports this interpretation. See John Hart Ely, Interclausal Immunity, 87 Va L Rev $1185,1193-94$ (2001).

85383 US 663 (1966).

86 See Keyssar, The Right to Vote at 269 (cited in note 8); Killian, Costello, and Thomas, The Constitution at 2107-08 (cited in note 9).

87383 US at $664 \mathrm{n} 1$ (declaring that exceptions to the state election poll tax were "not relevant here"). See also Ely, 87 Va L Rev at 1188 (cited in note 84) (noting that the Harper Court decided the issue only for state elections). 
termine voting rights in state elections. ${ }^{88}$ Douglas mentions the Twenty-fourth Amendment nowhere in his opinion, but the Amendment and Harper fit together tightly. ${ }^{89}$ The Twenty-fourth Amendment's reach ends at the federal ballot; Harper extends to the remaining state elections.

Although this formalistic reading restricts Harper's holding to state elections, the opinion's reasoning applies equally to federal elections through the judge-constructed equal protection component of the Fifth Amendment's Due Process Clause. The opinion's expansive language supports such an interpretation. Douglas concludes that:

[A] State violates the Equal.Protection Clause of the Fourteenth Amendment whenever it makes the affluence of the voter or payment of any fee an electoral standard. Voter qualifications have no relation to wealth nor to paying or not paying this or any other tax. Our cases demonstrate that the Equal Protection Clause of the Fourteenth Amendment restrains the States from fixing voter qualifications which invidiously discriminate."

Additionally, Douglas cites as complements to Harper two precedents striking down voter qualifications in both state and federal elections." Harper thus appears to essentially obviate any practical need for the Twenty-fourth Amendment. ${ }^{93}$ As one commentator puts it, "the net effect of the Twenty-fourth Amendment was, at most, to abolish the' poll tax in federal elections, in a few states, two years before it would have been abolished across the board anyway." Indeed, the

88 See Keyssar, The Right to Vote at 271 (cited in note 8) (noting, however, that "many Americans still believed that the dependent poor ought to remain disfranchised").

89 Justice Black's dissent also fails to mention the Twenty-fourth Amendment. See Harper, 383 US at 670-80 (Black dissenting) (noting that the majority eliminates those few poll taxes left after the Twenty-fourth Amendment). See also United States v Texas, 252 F Supp 234, 255 (WD Tex 1966) (finding poll taxes in state elections unconstitutional under the Due Process Clause of the Fourteenth Amendment); United States v Alabama, 252 F Supp 95, 108 (MD Ala 1966) (same).

90 See Bolling $v$ Sharpe, 347 US 497, 498-99 (1954) (arguing that "discrimination may be so unjustifiable as to be violative of due process," even without a textual claim that the federal government is bound by equal protection principles). See also United States $v$ Armstrong, 517 US 456, 464 (1996) (noting "the equal protection component of the Due Process Clause of the Fifth Amendment").

91 Harper, 383 US at 666.

92 See id at 666-67, citing Carrington v Rash, 380 US 89, 96 (1965) (striking down a statute prohibiting members of the military in Texas from voting) and Louisiana $v$ United States, 380 US 145,148 (1965) (invalidating an "interpretation test" as a prerequisite to voter registration).

93 See Keyssar, The Right to Vote at 262-63 (cited in note 8) ("[F]ew politicians in either party wished to antagonize a new bloc of voters by opposing their enfranchisement.").

94 David A. Strauss, The Irrelevance of Constitutional Amendments, 114 Harv L Rev 1457, 1459, 1481-82 (2001). See also Mark R. Killenbech and Steve Sheppard, Another Such Victory? Term Limits, Section 2 of the Fourteenth Amendment, and the Right to Representation, 45 Hastings L J 1121, 1206 n 442 (1994) ("The Twenty-Fourth Amendment was, however, arguably unnecessary 
Amendment plays little role in present-day jurisprudence. ${ }^{95}$ Douglas's expansive construction of the Fourteenth Amendment in Harper thus severely limits the Twenty-fourth Amendment's legal effect.

\section{B. Breadth}

Although the Twenty-fourth Amendment addresses only a discrete subset of elections, it creates a broad, absolute prohibition on voter qualifications that in any way implicate economic means. ${ }^{96}$ The Supreme Court's response to states' attempts to circumvent the poll tax ban illustrates a broad reading of the Twenty-fourth Amendment. When the Twenty-fourth Amendment's ratification appeared inevitable, some states attempted to modify their poll tax statutes to comply with the Amendment. Virginia, for example, enacted a measure "whereby the federal voter could qualify either by paying the customary poll tax or by filing a certificate of residence six months before the election." The Court found such provisions unconstitutional in Harman $v$ Forssenius. ${ }^{98}$ Writing for the majority, Chief Justice Warren espoused an expansive version of the Twenty-fourth Amendment's rights guarantee, stating that:

For federal elections, the poll tax is abolished absolutely as a prerequisite to voting, and no equivalent or milder substitute may be imposed. Any material requirement imposed upon the federal voter solely because of his refusal to waive the constitutional im-

given the Court's statement in Harper."). A second perspective is that Harper contravenes principles of constitutional interpretation by constructing the Fourteenth Amendment to reach conclusions precluded by the negative implications of the Twenty-fourth. See Cohens $v$ Virginia, 19 US 264, 398 (1821) ("The Court [in construing a provision of the Constitution] may imply a negative from affirmative words where the implication promotes, but not where it defeats, the intention.").

95 The influence of these legal sources shows in their citation count: Harper is a well-cited opinion (842 citing decisions), while the Twenty-fourth Amendment has evoked a comparatively miniscule amount of jurisprudential production (a mere 11 citations; 1.3 percent of Harper's count). LEXIS search, June 10, 2007.

96 See Hayden v Pataki, 449 F3d 305, 317 n 13 (2d Cir 2006) ("[P]oll taxes [were] expressly forbidden by the 24th Amendment."); Texas, 252 F Supp at 238-39 ("[T] he payment of poll taxes has been prohibited by the adoption of the Twenty-Fourth Amendment.").

97 Harman v Forssenius, 380 US 528, 540-41 (1965). See also Robert Brischetto, et al, Texas, in Chandler Davidson and Bernard Grofman, eds, Quiet Revolution in the South: The Impact of the Voting Rights Act 1965-1990 233, 239-40 (Princeton 1994) (describing the Texas legislature's efforts to replace its poll tax with "an almost equally onerous annual voter registration system").

98380 US 528, 544 (1965). Forssenius rests on the substantive scope of the Twenty-fourth Amendment's proscription because a mere procedural disjunction between state and federal election processes presents no constitutional problems. See Oregon v Mitchell, 400 US 112, 125-26 (1970) (invalidating a congressional statute lowering the voting age to eighteen insofar as it applied to state elections but upholding it for federal elections), superseded by US Const Amend XXVI (1971) (lowering the voting age to eighteen in both state and federal elections). 
munity subverts the effectiveness of the Twenty-fourth Amendment and must fall under its ban."

Twenty-fourth Amendment poll taxes effectively include excises on individuals' time and convenience, if those costs represent the alternative to a cash tax. Warren notes that, "like the Fifteenth Amendment, the Twenty-fourth nullifies sophisticated as well as simpleminded modes of impairing the right guaranteed."100 The rights created by the Twenty-fourth Amendment cannot be "indirectly denied." This broad reading of the Twenty-fourth Amendment's rights guarantee elevates the substance and effect of statutory voting requirements over their mere form. ${ }^{102}$

The textual hook for the Forssenius rule is that the Twenty-fourth Amendment prohibits voting rights from being "denied or abridged" by the failure to pay a poll tax. Had the Amendment proscribed denial only, the state statute might have survived. ${ }^{103}$ Under its actual, expansive verbiage, the Twenty-fourth Amendment bans poll tax schemes that "circumscribe or burden or impair or impede" voting rights. Courts have distinguished this kind of affirmative abrogation of voting rights from any fees or restitution payments required to reinstate those same rights, and such fees and restitution mandates are not unconstitutional poll taxes. ${ }^{105}$ This limitation, however, does not apply to tax felon disenfranchisement because the tax felony provokes the curtailment of voting rights, rather than preventing their restoration.

99 Forssenius, $380 \mathrm{US}$ at 542.

100 Id at 541, quoting Lane $v$ Wilson, 307 US 268, 275 (1939).

101 Forssenius, 380 US at 540-41, quoting Smith v Allwright, 321 US 649, 664 (1944). This interpretation matches the social tenor of the mid-1960s, when poll taxes were justifiably viewed as part of the effort by white Southern politicians to prevent blacks from voting. See Keyssar, The Right to Vote at ch 8 (cited in note 8).

102 Compare this argument for breadth in a constitutional provision with the form-oriented re-enactment rule for state disenfranchisement provisions enacted with improper intent. See text accompanying notes 75-80. See also Pollock v Farmers' Loan \& Trust Co, 157 US 429, 581 (1895) ("If it be true that by varying the form the substance may be changed, it is not easy to see that anything would remain of the limitations of the Constitution... But constitutional provisions cannot be thus evaded.").

103 See Forssenius, 380 US at 540.

104 See Gray v Johnson, 234 F Supp 743, 746 (SD Miss 1964) (per curiam; three judge panel) (holding unconstitutional a Mississippi statute requiring either a poll tax receipt or "an exemption certificate from the circuit clerk of the county" that provided comparable information).

105 Johnson v Bush, 214 F Supp 2d 1333, 1343 (SD Fla 2002); Howard v Gilmore, 2000 US App LEXIS 2680, *2 (4th Cir). But see Johnson, 405 F3d at 1216 n 1 ("[W]e say nothing about whether conditioning an application for clemency on paying restitution would be an invalid poll tax."), on appeal from Johnson, 214 F Supp 2d 1333. 
Although neither Forssenius nor any antecedent or subsequent lower court decisions discuss the scope of the phrase "other tax,"106 these cases read onto the Twenty-fourth Amendment a broad guarantee of substantive voting rights. If courts interpret the words "other tax" in a similarly expansive way, the formal separation of the federal income tax statute from state felon disenfranchisement provisions will not affect courts' construction of the laws' cumulative effect. The result if the two are coupled together-that nonpayment of federal income tax results in disenfranchisement - is all that matters.

\section{THE INCOME TAX AS A "POLl TAX OR OTHER TAX"}

The Twenty-fourth Amendment's strong ban on poll taxes indicates that, if the federal income tax is a "poll tax or other tax," nonpayment under the federal tax evasion statute cannot constitutionally trigger disenfranchisement. ${ }^{100}$ Case law has clearly established that income taxes are not "poll tax[es]." The plain meaning of the Twentyfourth Amendment's text indicates, however, that income taxes are almost certainly "other tax[es]." The Twenty-fourth Amendment's drafting history reveals no intent that contravenes the Amendment's text. Therefore, the disenfranchisement of tax felons is facially unconstitutional under the Twenty-fourth Amendment.

\section{A. Income Taxes as Poll Taxes}

"Income tax" connotes a different textual meaning than "poll tax," and courts have elaborated guidelines that distinguish the two. Although the Supreme Court has deemed both income taxes and poll taxes to be direct taxes, ${ }^{108}$ poll taxes are capitation taxes, while income taxes are assessed with reference to a person's "property, income, or ability to pay." ${ }^{109}$ Furthermore, those with incomes below a minimum threshold pay no income tax or even receive payments from the Treasury Department. ${ }^{110}$ Poll taxes, by contrast, fall uniformly on each

106 See generally Forssenius, 380 US 528, on appeal from Forssenius v Harman, 235 F Supp 66 (ED Va 1964) (three judge panel) (also ignoring the scope of "other tax"); Gray, 234 F Supp 743.

107 See Parts I, III.B.

108 See Pollock, 157 US at 579-80 (claiming that for classification purposes "[t]he name of the tax is unimportant."). Indirect taxes, such as excise taxes, are levied based on discrete events rather than discrete property. See id at 556.

109 Pekar v Commissioner, 113 TC 158, 165 (1999) (finding a "characterization of the [alternative minimum income tax] as a poll tax [to be] without substance"), citing Black's Law Dictionary 1159 (West 6th ed 1990).

110 See 26 USC $\$ 32$ (a) (2000 \& Supp 2005) (defining the earned income tax credit). 
voter - and can be avoided by foregoing the right to vote." As broad categories, income taxes and poll taxes are clearly distinct.

Marginal cases, however, blur the line between income taxes and poll taxes. For example, a state might enact a tax, due on voter registration, paid only by individuals earning income greater than a certain amount. This hypothetical tax almost certainly qualifies as an unconstitutional poll tax under Forssenius because it impairs citizens' exercise of the franchise, ${ }^{112}$ but its gross structure resembles an income tax. This zone of uncertainty between poll taxes and income taxes is policed by the Twenty-fourth Amendment's phrase "or other tax."

\section{B. Income Taxes as Other Taxes}

The plain meaning of the words "or other tax" includes federal income taxes. Because the evasion (and consequent nonpayment) of income tax can result in disenfranchisement, state provisions that revoke voting rights based on federal income tax felonies violate the Twenty-fourth Amendment. Although the Amendment's text is dispositive, this interpretation is corroborated by the Amendment's drafting history and purpose.

\section{Text.}

Constitutional interpretation starts by looking to the plain meaning of a provision's text. ${ }^{113}$ Only if the text is ambiguous may other modes of interpretation, such as purpose or intent, be used. ${ }^{114}$ The phrase "or other tax" is not ambiguous because its plain meaning includes income taxes. The operative word in the phrase is "other."

111 Pekar, 113 TC at 165.

112 See text accompanying notes 97-104.

113 Lake County v Rollins, 130 US 662 (1889) ("[W]hen the text of a constitutional provision is not ambiguous, the courts, in giving construction thereto, are not at liberty to search for its meaning beyond the instrument."); Rotunda and Nowak, Treatise on Constitutional Law $\$ 23.30$ at 267 (cited in note 9) ("Where a court considers the meaning of the word 'plain' and 'clear,'... the court will not use [collateral aids] to narrow or enlarge the text."); Laurence $H$. Tribe, 1 American Constitutional Law 87 (Foundation 3d ed 2000) ("[O]ne can reasonably impose a hierarchy of [interpretive] modes in descending order of agreed-upon legitimacy and force: text first."). But see Keith E. Whittington, Constitutional Interpretation: Textual Meaning, Original Intent, and Judicial Review 88-89 (Kansas 1999) (discussing the limits of text and the problems of indeterminacy); Rotunda and Nowak, Treatise on Constitutional Law $\$ 23.30$ at 267 (cited in note 9) (noting the finite extent to which "any words can be said to be ['plain' and 'clear']").

114 Rotunda and Nowak, Treatise on Constitutional Law \$\$23.31-.36 at 268-77 (cited in note 9) (listing other modes of interpretation). See also Tribe, 1 American Constitutional Law at 87 (cited in note 113) (listing a hierarchy of interpretive modes).

115 Webster's defines "tax" as a "pecuniary charge imposed by legislative or other public authority upon persons or property for public purposes." Philip Babcock Gove, ed, Webster's Third New International Dictionary 2345 (Merriam-Webster 1993). Income taxes fall under this definition. 
discern the plain meaning of words, courts examine dictionary usages." Webster's Third New International Dictionary lists four definitions for the adjective "other," three of which are pertinent:

1a: being the one (as of two or more) left: not being the one (as of two or more) first mentioned or of primary concern: remaining...

2a: not the same: different ...

3: more, additional. ${ }^{\mathrm{In}}$

Whether understood as "remaining," "different," or "additional," the word "other" captures all varieties of taxes aside from poll taxes. In addition, the disjunctive coordinator "or," which precedes "other tax," indicates that the category "other tax" must include items different from those in the "poll tax" category. ${ }^{118} \mathrm{~A}$ reading of "other" as restrictive - that is, as "poll tax or other [similar] tax"-matches neither the word's expansive plain meaning nor its structural place within the text. Because "other" is inclusive, income taxes qualify as an "other tax."

When interpreting the Constitution's plain meaning, courts will also consider the meaning of words in their broader context. ${ }^{119}$ The Twenty-fourth Amendment contains two syntactically similar uses of the word "other." One part of the Twenty-fourth Amendment addresses the "failure to pay any poll tax or other tax," while a second refers to "[ $t]$ he right ... to vote in any primary or other election." ${ }^{120}$ If "other" is defined restrictively in this second phrase, it targets only elections of a type similar to primaries. But courts have interpreted the Twenty-fourth Amendment to apply to any election, of which pri-

116 See, for example, Gonzales $v$ Raich, 545 US 1, 69 (2005) (O'Connor dissenting) (noting the breadth of the majority's definition of "economic" when addressing a Commerce Clause issue).

117 Webster's Third at 1598 (cited in note 115). Not only is Webster's Third used frequently by the Court, see, for example, Raich, 545 US at 69, but the last major revision was produced just three years before the Twenty-fourth Amendment's ratification. For an explication and critique of the Court's use of dictionaries, see generally Kevin Werbach, Note, Looking It Up: The Supreme Court's Use of Dictionaries in Statutory and Constitutional Interpretation, 107 Harv L Rev 1437 (1994).

118 Webster's Third defines "or" as "used as a function word to indicate (1) an alternative between different or unlike things, states, or actions." Webster's Third at 1585 (cited in note 115). Alternate uses that indicate, for example, "the synonymous, equivalent, or substitute character of two words or phrases" are too restrictive because they render ineffective the phrase "or other tax." See Knowlton v Moore, 178 US 41, 87 (1900) (noting the "elementary canon of construction which requires that effect be given to each word of the Constitution").

119 Cohens, 19 US at 398 ("In interpreting a provision of the Constitution, every part of the article must be taken into view and that construction adopted which will consist with its words and promote its general intention.").

120 US Const Amend XXIV, $\$ 1$ (emphasis added). 
maries are simply an exemplar. ${ }^{121}$ Because courts read "other" expansively in the second phrase, it must have a consistent meaning in the first. Although different parts of the Constitution have been interpreted to use "other" restrictively, ${ }^{122}$ the internal structure of the Twenty-fourth Amendment necessitates an expansive reading. Therefore, "other tax" includes levies beyond simple poll taxes, and income taxes fall within the Twenty-fourth Amendment's purview.

\section{Congressional intent.}

Although the unambiguous plain meaning of the Twenty-fourth Amendment appears dispositive, courts often turn to other modes of interpretation to augment the text. ${ }^{123}$ One such mode analyzes congressional history to discern the intent of a provision's authors. ${ }^{124}$ The

121 See Part II.A. Restrictions on this general category of elections arise from the prepositional phrase that follows it. See US Const Amend XXIV, $\$ 1$ (restricting elections to those "for President or Vice President, for electors for President or Vice President, or for Senator or Representative in Congress").

122 The principal example is that "other" crimes generally must match their specified predecessors in severity. See US Const Art II, $\$ 4$ ("Treason, Bribery, or other high Crimes and Misdemeanors"), Art IV, $\$ 2$ ("Treason, Felony, or other Crime"), Amend XIV ("rebellion, or other crime"); Ramirez, 418 US at 53-54. See also Tribe, 1 American Constitutional Law at 39 n 29 (cited in note 113) (noting repetitions of important phrases in the Constitution); Akhil Reed Amar, Intratextualism, 112 Harv L Rev 747, 781 n 149 (1999) (citing an online discussion with Laurence Tribe about the word "other"). See Amar, 112 Harv L Rev at 748 (proposing a mode of interpretation that holistically examines recurring "words and phrases" throughout the Constitution). This interpretation may reflect the longstanding judicial precept of the rule of lenity. Lenity, of course, favors a reading of "other" that includes as few additional crimes as possible. See Staples $v$ United States, 511 US 600,619 n 17 (1994) (defining the "rule of lenity" to require that an "ambiguous criminal statute is to be construed in favor of the accused"); United States $v$ R.L.C., 503 US 291, 305 (1992) (noting that the rule of lenity applies to "questions about the severity of sentencing"), citing Bifulco v United States, 447 US 381, 387 (1980).

123 See Stephen M. Griffin, Pluralism in Constitutional Interpretation, 72 Tex L Rev 1753, 1757 (1994) ("Pluralistic theories perform well in the descriptive-explanatory dimension because the Supreme Court does not use a single interpretive principle or method in making constitutional decisions."). While Griffin contends that "[t]he Court has never established a priority or ranking of [ ] different methods of interpretation," id, individual Justices have aligned themselves with specific schools of interpretation. See, for example, Antonin Scalia, The Rule of Law as a Law of Rules, 56 U Chi L Rev 1175, 1184 (1989) ("I am more inclined to adhere closely to the plain meaning of a text."). But see Griffin, 72 Tex L Rev at 1768 (arguing that even apparently monolithic theories, "such as Ely's interpretivism and Bork's originalism, are pluralistic theories in that they recognize at least two legitimate methods of interpretation - text and precedent - in addition to the particular methods on which they lavish most of their attention").

124 Looking for "intention" in the drafting history of constitutional amendments presents special problems, however. See Ramirez, 418 US at 43 ("The problem of interpreting the "intention' of a constitutional provision is, as countless cases of this Court recognize, a difficult one."). Congress's intent in promulgating an amendment (already an uncertain thing to discern) may not match the intent of the ratifying states. Id. And the states' intent may prove impossible to ascertain. As John Hart Ely put it, "we haven't a prayer of reconstructing" the states' "understanding" of the Twenty-fourth Amendment. Ely, 87 Va L Rev at 1193 (cited in note 84). Therefore, this inquiry focuses on Congress's perception of the Amendment's purpose. 
Twenty-fourth Amendment's drafting history indicates that the Amendment's authors sought two goals: to "strip[] away more of the legal camouflage that was sheltering discrimination" against Southern blacks and to increase voter turnout. ${ }^{12}$

The Twenty-fourth Amendment's drafters actively sought to remedy invidious racial discrimination in some states' regulation of the franchise. ${ }^{126}$ On the floor of Congress, the debate over the Twentyfourth Amendment highlighted the race angle. Southern senators and representatives decried the measure as an abrogation of states' rights and a poorly disguised effort by Northern politicians to win the urban African-American vote. In turn, these Northern politicians responded by alleging that the Southerners' federalism arguments merely masked base racial bias. ${ }^{127}$ Ending racial discrimination was a purpose of the Amendment, but it was not the sole purpose.

The House Judiciary Committee's report on the Twenty-fourth Amendment exposes a second goal: to increase voter participation in general. The report claims that:

[T]hese five States which still require payment of a poll tax were among the seven States with the lowest voter participation in the 1960 presidential election.

While it is true that the amount of poll tax now required to be paid in the several States is small and imposes only a slight economical obstacle for any citizen who desires to qualify in order to vote, nevertheless, it is significant that the voting in poll tax States is relatively low as compared to the overall population which would be eligible.... [T] he historical analysis [] indicates that where the poll tax has been abandoned[,] voter participation increased. ${ }^{128}$

Although black franchise rights loomed large in the background, the language of the report on its face displays an intent to increase voter turnout. ${ }^{129}$ And indeed, the voting rights reforms of the $1960 \mathrm{~s}$

125 Keyssar, The Right to Vote at 262 (cited in note 8).

126 Outlawing Payment of Poll or Other Tax as Qualification for Voting in Federal Elections, HR Rep No 1821, 87th Cong, 2d Sess 3, 5 (1962).

127 See, for example, 87th Cong, 2d Sess, in 108 Cong Rec 4153-55 (Mar 14, 1962).

128 Outlawing Payment, HR Rep No 1821 at 3 (cited in note 126). The empirical truth of these claims is less important than that the Amendment's drafters believed them to be true.

129 It can safely be assumed that tax felonies do not fall disproportionately on AfricanAmericans. See Comisky, Feld, and Harris, 1 Tax Fraud $\mathbb{1 1 . 0 1 [ 7 ] ~ a t ~ 1 - 2 0 ~ t o ~ - 2 1 ~ ( c i t e d ~ i n ~ n o t e ~ 1 4 ) ~}$ (describing the targets of tax evasion prosecutions as only those with very large amounts of unpaid tax at stake, which implies a predominantly white target population). Therefore, any intent of the Twenty-fourth Amendment's drafters to prevent the abrogation of blacks' voting 
produced substantial increases in the proportion of both blacks and whites who voted. ${ }^{130}$ Disenfranchising tax felons subtracts from the pool of eligible voters, while preventing tax felon disenfranchisement adds to that pool. ${ }^{131}$ Because neither choice produces a neutral effect, an expansive reading of "other tax," a reading that precludes tax felon disenfranchisement, better meshes with the intent of the Twentyfourth Amendment's drafters.

The Twenty-fourth Amendment's drafters also clarified an explicit purpose for the phrase "other tax." The drafters intended the phrase to be broadly prophylactic, according to the House report on the Amendment. By "prevent[ing] both the United States and any State from setting up any substitute tax in lieu of a poll tax as a prerequisite for voting," the phrase was to cabin either government's ability to "nullif[y] [ ] the amendment's effect by a resort to subterfuge in the form of other types of taxes." "132 Whether the Amendment permits, grandfathers in, or precludes tax felons, disenfranchisement remains unaddressed. Although the Amendment's drafters did not overtly contemplate that the phrase "other tax" might reach federal income taxes, they crafted a provision that addressed the substance of the poll tax problem rather than the mere form of contemporary poll taxes. ${ }^{133} \mathrm{By}$ inserting catchall language, the drafters chose to err on the side of expansive voting rights. A narrow reading of "other tax" allocates the risks of interpretive error in a way that directly contravenes the intent of the Amendment's drafters. The Twenty-fourth Amendment's drafting history, like its plain meaning, therefore supports a broad interpretation of the phrase "other tax" and the conclusion that tax felon disenfranchisement is unconstitutional.

rights probably is not effectuated by reading the Twenty-fourth Amendment to except tax felons from disenfranchisement.

130 Harold W. Stanley, Voter Mobilization and the Politics of Race 3-4 (Praeger 1987) (arguing that white voter turnout in the South increased more than black voter turnout after voting reforms in the mid-1960s).

131 But see Thomas J. Miles, Felon Disenfranchisement and Voter Turnout, $33 \mathrm{~J}$ Legal Stud 85,118 (2004) (using empirical evidence to suggest that felon "disenfranchisement has no discernible effect on voter turnout").

132 Outlawing Payment, HR Rep No 1821 at 5 (cited in note 126).

133 As Justice Marshall stated:

It is impossible to conceal from ourselves, that this is varying the form, without varying the substance. It is treating a prohibition which is general, as if it were confined to a particular mode of doing the forbidden thing. All must perceive, that a tax on the sale of an article, imported only for sale, is a tax on the article itself.

Brown v Maryland, 25 US (12 Wheat) 419, 444 (1827). 


\section{INTERPRETING THE TWENTY-FOURTH AMENDMENT}

The text, structure, and drafting history of the Twenty-fourth Amendment imply that the Amendment's broad voting rights guarantee bars states from disenfranchising tax felons. This conclusion, however, stands in tension with present-day understandings of the Twentyfourth Amendment's social, legal, and historical role, which casts the Amendment as substantively narrow in scope. ${ }^{134}$ To remedy this incongruity, courts should apply an additional interpretive layer when analyzing the Twenty-fourth Amendment. Before addressing the text, structure, and drafting history of the Amendment, courts should locate the provision within its social, political, and historical context, within a "preliminary frame" that guides the application of more conventional modes of interpretation. The Twenty-fourth Amendment's preliminary frame indicates that the Amendment represents a narrow intervention against a specific set of practices that do not include tax felon disenfranchisement. Therefore, courts should construe the Amendment to permit tax felon disenfranchisement. ${ }^{135}$

\section{A. The Role of the Twenty-fourth Amendment}

Present-day views of the Twenty-fourth Amendment promote an understanding of the Amendment's social, legal, and historical role as fundamentally limited. Scholars often cast the Twenty-fourth Amendment as a product of the Civil Rights Movement, as a sign of Whiggish progress towards a certain type of broad-based democracy. In terms of social and historical context, the Twenty-fourth Amendment fits with contemporaneous efforts to eliminate constraints on voting rights such as "literacy tests, understanding clauses, pauper exclusions, and good character provisions"; "durational residency qualifications"; "language barriers"; and "racial gerrymander[ing]." "136 The 1960s political rights milieu also generated the Twenty-Third and Twenty-Sixth Amendments, which widened the franchise by extending the vote to, respectively, residents of Washington, D.C.; and United

\footnotetext{
134 Scholars have noted an analogous tension involving Rehnquist's rigidly formalistic reading of the Fourteenth Amendment in Ramirez. See note 34.

135 Given that cheaper and easier routes to re-enfranchisement exist (and that tax felons may not care much about voting anyway), it seems somewhat implausible that a plaintiff will press this issue in court.

136 See Keyssar, The Right to Vote at 281-82 (cited in note 8); Klarman, From Jim Crow at 340 (cited in note 8) (noting the effect of a "racial gerrymander"). See also Keyssar, The Right to Vote at ch 8 (cited in note 8 ).
} 
States citizens between the ages of eighteen and twenty-one. ${ }^{137}$ This concerted expansion of the electorate, however, had (and has) clear political and social limits, as evidenced by the persistent exclusion of convicted felons from voter rolls. ${ }^{138}$ The Twenty-fourth Amendment represents not a broad statement of rights, but rather a closely titrated effort to remedy a specific perceived problem.

The Twenty-fourth Amendment's limited effect on the law both at ratification and at present supports an understanding of the Amendment as a discrete intervention at a specific historical moment. Arguably, the Twenty-fourth Amendment's principal effect was to bring "the stragglers" - the five holdout poll tax states - "into line" with the majority. ${ }^{139}$ Further mitigating this effect is the strong possibility that "the outliers might not have held out much longer against the nearly unanimous opposing consensus even if there had been no constitutional amendment." ${ }^{140}$ By 1964, the Amendment was legal "window-dressing," a trophy for the hard-fought social battles over civil rights. ${ }^{141}$ The ascendancy of Fourteenth Amendment voting rights under Harper and the paucity of case law on the Twenty-fourth Amendment indicate that the Twenty-fourth Amendment has little lasting import beyond its initial symbolic value. ${ }^{142}$ It seems patently incongru-

137 For discussions of this spate of amendments, see George Anastaplo, The Amendments to the Constitution ch 16 (Johns Hopkins 1995); Alan P. Grimes, Democracy and the Amendments to the Constitution ch 5 (Lexington 1978).

138 See Keyssar, The Right to Vote at 308 (cited in note 8) ("Although race, class, mobility, literacy, and the ability to speak English have ceased to be formal impediments to voting, good behavior is still required."). See also Klarman, From Jim Crow at 340 (cited in note 8) (noting whites' willingness in the 1960 s to remove barriers to blacks' ability to vote but unwillingness to support public school desegregation).

139 Strauss, 114 Harv L Rev at 1461 (cited in note 94). Note, however, that only eleven states historically employed poll taxes, so the five outstanding at the Amendment's ratification represented a substantial portion of the offenders. See Grimes, Democracy and the Amendments to the Constitution at 130-31 (cited in note 137) (discussing the history of the Twenty-fourth Amendment proposals).

140 See Strauss, 114 Harv L Rev at 1459, 1461 (cited in note 94). But see Brandon P. Denning and John R. Vile, The Relevance of Constitutional Amendments: $A$ Response to David Strauss, 77 Tulane L Rev 247, 264-65 (2002) ("For someone living in an outlier state, it is cold comfort to be told that change will 'eventually' come 'soon.").

141 See Strauss, 114 Harv L Rev at 1482 (cited in note 94). See also Gerald N. Rosenberg, The Hollow Hope: Can Courts Bring about Social Change? 22 (Chicago 1991) (noting that courtdriven constitutional change occurs without, and often contrary to, majority public opinion).

142 See notes 94-95 and accompanying text. See also Part III.A. Even if the Twenty-fourth Amendment had a substantial (but indirect) immediate effect, it has nominal ongoing importance compared to the constitutional provisions it affected. In this sense, the Twenty-fourth Amendment may represent a harbinger of constitutional change, an Amendment that shifts many meanings across the Constitution instead of appending a single meaning to the document. See Jamin B. Raskin, Is There a Constitutional Right to Vote and Be Represented? The Case of the District of Columbia, 48 Am U L Rev 589, 659 (1999) (noting that Harper "emphasiz[ed] that the historical meanings of equal protection do change" and that the Twenty-fourth Amendment 
ous for the Amendment's lasting legal legacy to be to exempt tax felons - a relatively minor subcategory of criminals - from the application of otherwise-constitutional disenfranchisement statutes. Mechanical interpretation of the Twenty-fourth Amendment therefore produces a result that radically alters the Amendment's social, legal, and historical meaning, as understood from a present-day vantage point. ${ }^{143}$

\section{B. Preliminary Frames and Constitutional Interpretation}

The tension between the Twenty-fourth Amendment's social, legal, and historical role and the Amendment's meaning under traditional interpretive modes can be remedied by addressing the general scope of the Amendment before invoking more conventional methods. This "preliminary frame" guides the application of text, structure, drafting history, purpose, and other methods of interpretation by limiting the types of interpretive questions that can be asked about the Twenty-fourth Amendment. In particular, a preliminary frame asks whether the Amendment, as a whole, should be viewed broadly or narrowly. ${ }^{144}$ More generally, the preliminary frame categorizes "some of the Constitution's provisions ... as enacting fairly abstract principles, and others as enacting quite concrete rules." ${ }^{, 45}$ This type of preliminary frame avoids a principal peril of rote interpretation: that the Constitution will be inappropriately read "with mathematical nicety to logical extremes." ${ }^{146}$ In addition, the preliminary frame clarifies the

changed those historical meanings). But see Laurence H. Tribe, Taking Text and Structure Seriously: Reflections on Free-Form Method in Constitutional Interpretation, 108 Harv L Rev 1221, 1288 (1995) ("Not all constitutional change is created equal. The theories that one might adopt to explain 1787 or 1866 are not useful for analyzing the adoption of ordinary constitutional amendments.").

143 Indeed, the constitutional nature of this incongruity also largely insulates it from social and political change. See Antonin Scalia, Common Law Courts in a Civil Law System, in Amy Gutmann, ed, $A$ Matter of Interpretation 3, 37 (Princeton 1997) ("[T] tion tells us not to expect nit-picking detail, and to give words and phrases an expansive rather than narrow interpretation - though not an interpretation that the language will not bear."). This intractable situation represents the converse of situations in which "alterations in social understandings and private sector behavior" substitute for constitutional change. Strauss, 114 Harv L Rev at 1462 (cited in note 94).

144 Phrased this way, a preliminary frame is similar to a decision over whether a statute applies at all, well before any interpretation of the statute itself is needed. See Frank H. Easterbrook, Statute's Domain, 50 U Chi L Rev 533, 544 (1983) ("My suggestion is that unless the statute plainly hands courts the power to create and revise a form of common law, the domain of the statute should be restricted to cases anticipated by its framers and expressly resolved in the legislative process.").

145 Laurence H. Tribe, Comment, in Gutmann, ed, A Matter of Interpretation 65, 68 (cited in note 143).

146 Paddell v New York, 211 US 446, 450 (1908) (Holmes). See also Kathleen M. Sullivan, Constitutional Constancy: Why Congress Should Cure Itself of Amendment Fever, 17 Cardozo L Rev 691, 691-92 (1996) (recognizing that the Constitution "is extraordinarily difficult to amend" and "thus remains a remarkably pristine document"). 
stakes of interpretation by focusing debate on the Amendment's functional role and away from the intellectual merit of specific modes of interpretation. $^{147}$

The idea of a preliminary frame is not unprecedented; indeed, such a concept offers a possible explanation for areas of constitutional law that appear disconnected from the Constitution's text. Judicial interpretations of the Ninth and Eleventh Amendments provide examples of these apparently extratextual readings. The Ninth Amendment states that " $[\mathrm{t}]$ he enumeration in the Constitution, of certain rights, shall not be construed to deny or disparage others retained by the people." By its plain language, the Ninth Amendment recognizes the existence of federally enforceable substantive rights beyond those explicated by the Constitution. ${ }^{148}$ The Supreme Court, however, understands the Amendment to merely affirm that the Constitution makes a positive grant of enumerated powers to the federal government. ${ }^{149}$ It "is simply a rule about how to read the Constitution" 150 and "far removed from affirming any one of [those other, unenumerated rights]." A preliminary frame analysis helps reconcile the Court's Ninth Amendment jurisprudence with conventional modes of constitutional interpretation. Framing the Ninth Amendment as a fundamentally narrow provision-and not a broad grant of individual rights-constrains the range of textual meanings that the Amendment can support. $^{152}$

147 Indeed, this shift in focus allows courts to directly engage larger themes in constitutional law. See David M. Driesen, Standing for Nothing: The Paradox of Demanding Concrete Context for Formalist Adjudication, 89 Cornell L Rev 808, 859-64 (2004) (describing the scholarly debate on whether constitutional adjudication deals principally with the "rights of individuals" or "the validity of legal rules").

148 See Griswold v Connecticut, 381 US 479, 493 (1965) (Goldberg concurring) ("[T]he Ninth Amendment ... is surely relevant in showing the existence of other fundamental personal rights."). See also Randy E. Barnett, The Ninth Amendment: It Means What It Says, 85 Tex L Rev 1, 2 (2006) ("The purpose of the Ninth Amendment was to ensure that all individual natural rights had the same stature and force after some of them were enumerated as they had before.").

149 See Doe v Bolton, 410 US 179, 210 (1973) (Douglas concurring) ("The Ninth Amendment obviously does not create federally enforceable rights."). See also United Public Workers $v$ Mitchell, 330 US 75, 95-96 (1947) ("If granted power is found, necessarily the objection of invasion of those rights, reserved by the Ninth and Tenth Amendments, must fail."); Barnett, Ninth Amendment, 85 Tex L Rev at 2 (cited in note 148) ("[T]he Supreme Court has long dismissed the Ninth Amendment as a constitutional irrelevance.").

150 Laurence H. Tribe, American Constitutional Law 776 n 14 (Foundation 2d ed 1988).

151 Troxel v Granville, 530 US 57, 91 (2000) (Scalia).

152 See Akhil Reed Amar, The Bill of Rights 123-24 (Yale 1998) (reading the preReconstruction Ninth Amendment as a narrow attempt to "elegantly integrate popular sovereignty with federalism"). The stickiness of a preliminary frame that looks to historical usage may explain why interpretations of the post-Reconstruction Ninth Amendment retain a narrow cast. See id at 124. 
The Eleventh Amendment presents the converse of the Ninth Amendment: the Court has read the textually narrow Eleventh Amendment as an expansive grant of rights rather than a narrow legal rule. The Eleventh Amendment bars the extension of "[t]he Judicial power of the United States ... to any suit in law or equity, commenced or prosecuted against one of the United States by Citizens of another State, or by Citizens or Subjects of any Foreign State." Although the Eleventh Amendment's text implicitly permits suits by citizens against their own state, the Court has consistently found such suits to violate sovereign immunity. ${ }^{153}$ A preliminary frame can explain this incongruence without abandoning textual modes of interpretation. Framed as a broad statement of sovereign immunity principles (and not as a narrow list of rules), the Eleventh Amendment's text implicitly permits extensions of sovereign immunity beyond the listed cases. Even for closely contested issues such as Eleventh Amendment sovereign immunity, ${ }^{154}$ a preliminary frame clarifies the stakes of the constitutional inquiry, and debate over the Eleventh Amendment should focus explicitly on the Amendment's basic scope before turning to the merits of various modes of interpretation..$^{155}$

\section{Framing the Twenty-fourth Amendment}

A preliminary frame for the Twenty-fourth Amendment casts it as fundamentally narrow in terms of its social, legal, and historical role-and therefore as inapplicable to tax felon disenfranchisement. This preliminary frame resolves an internal tension between the Twenty-fourth Amendment's broad and narrow aspects. At present, courts view the Amendment as operating narrowly in terms of its application (only to federal elections) but broadly in terms of its categorical prohibition (against poll taxes in any form) ${ }^{1.56}$ When considering whether the Twenty-fourth Amendment addresses the disenfranchisement of tax felons, courts should cast the Amendment as either entirely broad or entirely narrow. An entirely broad Amendment would encompass the payment of income taxes and forbid tax felon disenfranchisement, while an entirely narrow Amendment would not

153 See Alden v Maine, 527 US 706, 707 (1999) ("[T]he [Eleventh] Amendment confirmed rather than established sovereign immunity as a constitutional principle."); Hans $v$ Louisiana, 134 US 1, 10 (1890) (noting that a textual reading of the Eleventh Amendment produces an "anomalous result").

154 Alden, for example, was a 5-4 decision, in which Justices Souter, Stevens, Ginsburg, and Breyer all dissented.

155 See Lawrence B. Solum, Originalism as Transformative Politics, 63 Tulane L Rev 1599, 1624-25 (1989) (describing intellectual and philosophical inconsistencies in Eleventh Amendment jurisprudence).

156 See Part III. 
touch antecedent established practices, such as felon disenfranchisement, and would abrogate only 1964 poll taxes and prospective measures of a similar sort with a similar effect. In light of present-day understandings of the Amendment - and in contrast to present-day understandings of prototypically broad constitutional amendments, such as the Fourteenth Amendment - an entirely narrow reading is most appropriate. ${ }^{157}$ Because a preliminary frame casts the Twenty-fourth Amendment as narrow and rule-like, ${ }^{158}$ the Twenty-fourth Amendment's phrase "other tax" should not encompass income taxes.

\section{CONCLUSION}

The text, structure, and drafting history of the Twenty-fourth Amendment notwithstanding, the Amendment's ban on any "poll tax or other tax" should not include income taxes, leaving tax felon disenfranchisement constitutional. This extratextual interpretation, which stems from the application of a "preliminary frame" that considers the Twenty-fourth Amendment's scope in light of its social, legal, and historical role, ameliorates the tension between felon disenfranchisement laws and the Twenty-fourth Amendment. In addition, the concept of a preliminary frame sheds light on other apparently extratextual interpretations of the Constitution, such as those involving the Ninth and Eleventh Amendments. Indeed, preliminary frames may even provide useful guidance in addressing parts of the Constitution that produce divergent meanings under different interpretive modes.

157 See Tribe, Comment at 68 (cited in note 145) (arguing that the broad Fourteenth Amendment might even, "in light of its broad language and its uncertain reach, end up condemning some of what [its authors and ratifiers] then regarded as entirely just and proper").

158 As views on the Amendment's social, legal, and historical roles change, the Amendment's breadth or narrowness may also change. See id at 69 (noting that not "all constitutional provisions may be neatly classified at birth ... [as either] broad and dynamic statements of abstract principle ... [or as] dated, static, and concrete rules"). 